\title{
4. Pathology of Love as Gender Domination: Recognition and Gender Identities in Axel Honneth and Jessica Benjamin ${ }^{1}$
}

\author{
by Federica Gregoratto
}

\section{Introduction}

Despite many controversies, Hegel has always been a significant reference point for feminist thinkers. ${ }^{2}$ Many social philosophers, as well as political and critical theorists, have explicitly made use of Hegelian arguments in order to elaborate different kinds of gender-related issues. ${ }^{3}$ There is one Hegelian category in particular that is, I believe, especially appealing for the critical reconstruction of a certain type of intersubjective relationship: the relationship between man and woman. This is the idea of mutual recognition (Anerkennung). While having recently become one of the key concepts of political and social philosophy, the idea of recognition has not yet had a similarly fruitful impact on feminist, gender theory or queer theory debates. ${ }^{4}$

The aim of the present essay is to draw on the concept of recognition that appears in the work of Axel Honneth and Jessica Benjamin in order to critically investigate a certain form of gender domination. This form of domination I will interpret as a pathology of love. The pathology of love I am interested in particularly concerns the heterosexual sentimental bond; the relation of recognition between the subjectivity characterized by the gender identity of man and the subjectivity characterized by the gender identity of woman. $^{5}$

As Iris M. Young has acknowledged, Honneth's theory of recognition offers "many resources for feminist social criticism" (Young 2007, 193). In particular, Honneth intends to challenge the gender division of labor that denigrates women's work, as well as to support feminist calls for recognition of unpaid domestic work and for the revaluation of typically female jobs in the paid workforce. ${ }^{6}$ Still, Honneth's theory of recognition qua love, Young states further, does not provide "a conception of reciprocity in sexual love" that might "replace the complementary ideology of the modern bourgeois conception of conjugal love" (Young 2007, 193).

According to this type of ideology, first put forth by Rousseau, the normative model of the relations between man and woman consists in a 
mutual, yet not egalitarian, form of recognition between them. Within a marriage based on love, both man and woman recognize the spouse as, at least to a certain extent, an autonomous person whose needs demand satisfaction. The woman recognizes the man insofar as she, by being a good wife, mother, housekeeper, caregiver, etc., provides emotional support for him; her recognition is crucial for helping him face the public world of competition for honor, success and power. The man can enjoy this kind of recognition only if he, in turn, recognizes the woman as someone with a mind of her own, namely, as someone who autonomously chooses to satisfy her husband's needs and desires. The husband does not only appreciate his wife for being an intelligent, educated, caring, sweet, chaste, humble woman, he also recognizes her financially, that is to say, he sustains her. In this way, the union between husband and wife is a complementary one. The man is "active and strong," while the woman is "passive and weak" (Rousseau 1979, 322), and it is precisely these differences that put both of them in the position to satisfy the other's desires and needs.

According to Young, although Honneth does not explicitly endorse this model of a love relationship, he does not concretely outline a convincing alternative either. His only suggestion is that relations between men and women must be regulated by a universalistic legal system that guarantees equal rights for all individuals, thus protecting them (women in particular) against abuses in the sphere of love. ${ }^{7}$

Even though the complementary ideology of love has been questioned and challenged in several ways, both on theoretical and practical levels, Young states it still retains "many cultural and affective roots." She fears that "we have not replaced this conjugal model on a society-wide basis with realistic egalitarian free and mutual practices of sexual love" (Young 2007, 205). I agree with her on this point. ${ }^{8}$ More conceptual work is thus needed in order to sketch out the normative idea of egalitarian, happy and free love, and to diagnose the pathologies that may affect it.

In what follows, I argue that resources for contributing to such conceptual work can be found in Honneth's theory, especially in his reconstruction of what I call the normativity of interdependence, which regulates relations of loving recognition (1). Honneth's argument, however, has to be further developed with recourse to the work of Jessica Benjamin, who shows how the interdependence bond is to be understood as implying mutual exercises of power (2). Furthermore, I propose, following Benjamin's intuition, to interpret the pathologies of loving recognition as disruptions of the interdependence relation and as transformations of power into gender domination. Such disruptions, I will argue, are due to the emergence of the sharp opposition between the identities of man and woman, namely, between 
an identity privileging independence and an identity privileging dependence as their peculiar constitutive features (3).

\section{Interdependence as Normativity of Love}

In The Struggle for Recognition (Honneth 1995), Honneth reconstructs the normativity inherent in the sphere of love, mostly parental love, from an anthropological-psychological perspective. In this text, love stands for the most corporal, material and immediate mode of reciprocal recognition, which represents the first necessary condition for the formation of individual subjects and for a successful development of their identities. Honneth claims that in love,

[S]ubjects mutually confirm each other with regard to the concrete nature of their needs and thereby recognize each other as needy creatures. In the reciprocal experience of loving care, both subjects know themselves to be united in their neediness, in their dependence on each other. (Honneth 1995, 95; emphasis added)

The normative core of love - what makes it a successful, happy and free relation - is conveyed by the iconic Hegelian formulation of "being with oneself in another." Self-realization in and through the other does not mean, however, that the co-dependent partners have to be symbiotically merged. The interdependence bond is rather constituted as a precarious balance between independence, or "individual self-assertion", and deep attachment, or "self-sacrifice" (Honneth 1995, 96).

In order to make sense of such a tension between dependence and independence, Honneth concentrates on the love relation between parent (mother) and child as explained by Donald Winnicott. In particular, Honneth analyses the intersubjective process in which mother and child break their "undifferentiated oneness" (primary intersubjectivity), marked by "absolute dependency," and learn to accept and recognize each other as separated beings. In this process, each partner in the relation tries to become independent of the other; this does not imply, however, the eradication or the removal of dependence. It is precisely the dependence bond that fosters and brings about independence: it is only thanks to the loving care and to the constant confirmations of the mother that the child "learns" how to achieve independence (how to be alone for a while, to engage on her own with the external world, etc.). The primary forms of the child's self-sufficiency cause the mother to recognize her child as an independent being. Furthermore, the acknowledgement (also primitive forms of acknowledgement) of the dependence upon the partner is made possible only by the partner's 
independence: the child comes to feel her dependence upon the mother only if the mother stands and acts as an independent self - most importantly, as she is able to deny the child immediate gratification of her needs and desires.

Recognition qua love, especially conceived as parental love, is to be regarded as a relationship that progressively constitutes the independent self - an independent self who, in order to achieve independence and maintain herself as independent, has to be tied in a bond that makes her dependent on the other and on her loving recognition:

This release into independency has to be supported by an affective confidence in the continuity of shared concern. Without the felt assurance that the loved one will continue to care even after he or she has become independent, it would be impossible for the loving subject to recognize that independence. Because this experience must be mutual in love relationships, recognition is here characterized by a double process, in which the other is released and, at the same time, emotionally tied to the loving subject. (Honneth 1995, 107)

In his latest book, Freedom's Right (Honneth 2014, 152), Honneth investigates love, but not from the angle of the parent-child bond. Rather, in this work, he concentrates on the institutionalization of personal relationships (friendship, intimate relations, family) in modern, western societies. Honneth's main concern here is to show how intimate relations, based on romantic or erotic love, constitute a social sphere in which freedom is actualized.

In Freedom's Right, it is possible to trace at least two senses in which one can think of love as the actualization of freedom. First, the erotic relation is regarded as institutionalized within an autonomous social sphere (Honneth 2014, 152). Modern love is regulated by its own normativity, which appears as disentangled from other imperatives, most importantly from economic ones. In love affairs the choice of the love partner is free, that is, Honneth states, entirely based on sexual desire and mutual affection and not led by economic motivations or class biases.

Second, Honneth argues that in love relations "our inner nature is set free by mutual confirmation" (Honneth 2014, 132):

[I]n the social form of love as we know it today, each person is a condition for the freedom of the other by becoming a source of physical self-experience for the other; each person's natural being thus strips off its socially imposed constraints and recovers in the other a piece of his or her original freedom 
[Ungezwungenheit]. In the intimacy of love, being with ourselves in the other therefore means recovering the natural neediness of our own self in physical interaction, without fear of being humiliated or hurt. (Honneth 2014, 151)

In "being with oneself in the other," each partner represents the "condition for the freedom of the other." As I read it, this means that the mutual satisfaction of each lover's needs allows, for both partners, a "selfexperience" that sets the condition for realizing oneself as an autonomous and free agent. The love relationship can be thus regarded as an ongoing process, in which one develops and reinforces self-knowledge and selfconfidence, thus becoming able to discover and realize one's own desires and projects. ${ }^{9}$ One can say that, similarly to the mother-child bond, the romantic-erotic relationship consists of processes of recognition in which the partners develop and realize themselves as independent agents, and they do so by relying on their bond of mutual dependence. ${ }^{10}$ Within this context, an independent agent can be roughly defined as someone who has a certain awareness of her own desires and needs, and who is able to set goals and elaborate projects that can be pursued and achieved.

Each agent is deeply dependent on the confirmations, care, physical appreciation and satisfaction provided by the partner, and it is precisely such mutual reliance that makes independence and, therefore, self-realization possible. It follows that each partner in the relationship is free, namely, able to realize herself in another insofar as each is recognized by the other as entitled to the same "right to freedom."

More explicitly than in previous works, then, Honneth thinks here of gender equality as a crucial normative feature of loving recognition. Although Honneth does not say it explicitly, we can say that partners in a love relationship are equal if each one can enjoy the same kind and the same degree of freedom. Both partners are equally free if each can rely on the other for the realization of their needs. Such reliance is the condition ${ }^{11}$ that allows them to figure out and pursue their own aims and projects, thus exercising their independence.

\section{Love and Power}

Honneth asserts, as already mentioned, that in the social sphere of love each partner "strips off its socially imposed constraints," "recovers in the other a piece of his or her original freedom," and has no "fear of being humiliated or hurt" (Honneth 2014, 151). This suggests that lovers are able to enjoy forms of spontaneity, carefreeness and ease that do not characterize other 
social spheres (e.g. the political arena or the labor market). These considerations suggest that the sphere of love could be considered as largely disentangled from other social (cultural, political, economic) spheres. This is, however, not plausible: Everything that can be seen as constitutive for agents' identities (needs, desires, expectations, patterns of behavior, habits, beliefs, etc.) has been molded or influenced by many different social processes and cannot be just cancelled or bracketed as agents enter the sphere of love. Socially imposed constraints are thus essential components of agents' identities, and agents' identities play a fundamental role in love relations.

What could it mean, then, to say that lovers are able to dismiss their social chains and to regain a piece of original freedom? I propose to interpret it by drawing on the normativity of interdependence. This is to say, one might interpret the stripping off of social chains as that process in which, as a result of the dynamic of recognition, the chains are being shaken, loosened or even broken. Within the relation of recognition qua love, agents' identities (their needs, desires, expectations, habits, etc.) undergo a process of being challenged and transformed. We can call this process the transformative force of love (or better said, of recognition qua love).

Now, I argue that the category of power can help us to better understand such a transformative force. In order to reconstruct the relation of loving recognition as entailing some kind of exercise of power, I draw now on the work of the American psychoanalyst Jessica Benjamin, who has made a decisive contribution to the casting of the theory of recognition as a form of feminist critical theory. Especially in her early work, Benjamin describes the love bond between mother and child as a struggle for recognition, which she casts also as a power struggle. The core idea of this account is that power is linked to independence: the struggle for recognition appears mainly as a struggle for achieving independence. In order to be recognized as an independent agent, to assert it, one has to break the dependence bond and this implies and requires an exercise of power.

Jessica Benjamin refers to the bond between dependence and independence in more negative terms than Honneth does. In order to underline the negative, tormented moment inherent in the dynamic of loving recognition, Benjamin refers to the interrelation between dependence and independence as a "paradox" or "crisis of recognition." The paradox is never resolved, but "remains as a tension between self-assertion and recognition" (Benjamin 1995, 90). The categories of power and domination are introduced precisely with the aim of giving an account of such a paradox or crisis. In her first book, The Bonds of Love (1988), Benjamin contends that, 
The dynamic of destruction and survival is the central pattern of erotic union. In erotic union, the other receives and recognizes the subject's acts including his acts of destruction. Eros is certainly not free of all that we associate with aggression, assertion, mastery, and domination. But what makes sexuality erotic is the survival of the other with and despite destruction. (Benjamin 1988, 73)

In speaking in terms of "acts of destruction," Benjamin refers to the Winnicottian theory according to which the child performs a series of little, more or less symbolic, aggressive acts towards some objects and the mother's body, aiming to prove the existence of external objects, separated from the self (Benjamin 1988, 38ff.). The preliminary consciousness of external, alien objects enables the child to develop a preliminary self-consciousness as a separate unit.

We can say that by attacking the mother, the child tries to exercise power over her and, at the same time, to gain her recognition, which, as we have seen, constitutes the child as an independent self. Such a process is successful, according to Benjamin, if the mother is able to exercise some kind of counter-power, that is, if she can endure the child's attacks and prove to be indestructible. To be indestructible means to be an independent person, able to resist the child's immediate volition - an independent person who, however, neither leaves nor breaks the relation, who remains there to satisfy needs and grant recognition.

What precisely does power mean here? Since Benjamin does not provide a clear definition, let me try to reconstruct it in the following steps:

a) An agent $\mathrm{A}$ exercises power over another agent $\mathrm{B}$ when $\mathrm{A}$ makes $\mathrm{B}$ do (or not do) something that A wants B to do (or not to).

b) $\mathrm{A}$ is in a position of power over B - regardless of the fact that power is de facto exercised or not - if $\mathrm{A}$ is able to make $\mathrm{B}$ do (or not do) something that A could want B to do (or not to).

c) If it is the case that B does not want to do what A wants her to do (or not to), B may moreover exercise a counter-power. $\mathrm{B}$ exercises a (counter-)power over $A$, or gains a position of power over $A$, if $B$ is able to resist A's exercise of power and, eventually, make A do (or not do) what B wants A to do (or not do).

This definition seems to suggest that both A and B must already be 
independent agents (at least to a certain extent) in order to come to occupy a position of power and to effectively exercise power. How can the child come to occupy the position that enables her to exercise power over the mother? According to the model of loving recognition that I have been reconstructing so far, the child becomes an agent who is able to exercise power precisely as a result of the power exercised by the mother over the child. The mother makes the child do what she wants her to do, including (and most importantly) letting her separate and become independent. The child, in fearing the loss of her mother, comes at the same time to feel (and fear) her dependence on her. The dependence bond is perceived as a dangerous situation, against which the child rebels. The child begins thus to challenge the dependence bond by attacking the mother and trying to exercise her influence over her. In turn, the mother's power is exercised insofar as she is able to resist the child's attack and to stop, deny and re-direct her requests, whilst reassuring the child with her loving presence. The mother's power consists in the fact that she can "absorb and appreciate, and still set limits to the child's excitement and aggression" (Benjamin 1988, 121). ${ }^{12}$ These mutual exercises of power constitute the relational condition under which the child acquires and develops an independent (autonomous and capable) self. Note that the mother too, who is already an independent person in some respects, has to learn, within this relationship, how to exercise her own independence - how to separate from the child, to endure her protests and to resist her flattery or manipulations. Exercising power thus means breaking, undermining, and loosening dependence; these exercises are aimed at achieving independence. The condition under which this process can work does still reside, however, in the dependence bond in which each agent needs the other for the satisfaction of her physical and emotional needs. ${ }^{13}$

How can such a dependence-independence intertwinement, which requires mutual exercises of power, be seen as entailing the transformative force of love? I am going here beyond Benjamin's text, which does not provide insights, at least not explicit ones, to make sense of such force. In the parent-child relationship, the answer appears as rather clear. It is precisely within and thanks to the parental bond that both child and mother constitute and constantly change their subjectivities and identities. ${ }^{14}$ But can we think of such a transformative force also in the case of romantic-erotic relationships? I have previously argued that romantic-erotic love consists of processes of recognition in which the agents develop and realize themselves as independent, that is, as able to discover their own particular desires and needs and to satisfy them. But as we have seen in the parental relationship, power is a fundamental component in the process of achieving, proving and 
consolidating independence.

As such, I will now argue that power functions in the same way in romantic-erotic love. Exercises of power are required in order to continuously (re-)negotiate and (re-)establish both partners' independence. Thus, it is not just that each partner helps the other to realize her or his own independent self, but that they can only be that helpful insofar as they are both, so to say, subjects and objects of power. So, in the love relationship between $\mathrm{A}$ and $\mathrm{B}, \mathrm{A}^{\prime}$ s independence can be achieved by challenging, loosening and undoing the dependence bond that ties $A$ to $B$, and vice versa. The relation between A and B blooms, develops and changes insofar as B is able to recognize $A$ in her newly achieved independence, and vice versa.

Why should this idea of a love relationship entail a transformative potential? The power struggles consist in the challenging of the dependence bonds in order to assert oneself as independent and to be recognized as such. We have already said that partners deeply depend on each other for the satisfaction of their needs and desires, and this provides self-experience and self-knowledge. In the case of adult lovers, needs and desires, as well as expectations, plans, dreams and projects, are part of the agent's identity baggage. The challenging of the dependence bond corresponds then to the challenging of those elements in agents' identities that ground dependence. A relation of loving recognition that entails power struggles, one in which mutual dependence and strive for independence are deeply interwoven, is a relation that may lead to a transformation of the parts of those identities in which dependencies are rooted. Hence, in a love relationship, social chains are stripped off because the agents have the chance, and the power, to transform them. ${ }^{15}$

\section{Gender Domination as Pathology of Loving Recognition}

In the previous sections, I have reconstructed the normative infrastructure of a free love relationship ${ }^{16}$ by outlining the idea of interdependence underlying relations of recognition. Mutual exercises of power are constitutive for this kind of interdependence. How, then, can love become pathological? There is a kind of pathology, I argue, that is to be understood as gender domination. I propose that we can understand this form of pathology in terms of the splitting and polarization of the bond between dependence and independence, with one party falling on the side of dependence (women) and the other on the side of independence (men). As a result, power is exercised unilaterally, that is to say, it becomes mastery of one party over the other - the one representing independence, whereas the other appears doomed to dependence. 
Some theories of gender domination have already, in various ways, framed their central concern starting from the asymmetry between independence and dependence. Especially in traditional relationships (heterosexual, monogamous, etc.), domination has been defined as that bond - mostly a love bond ${ }^{17}$ - that holds women in a position of dependence on men that results in, and at the same time is generated by, men's denial of their dependence on women. I do not want to argue, however, that gender domination arises from the fact that women are more dependent on men (on men's esteem and support, both material and emotional) than men are on women. Rather, the argument is that the pathology of love conceived as gender domination results from the dynamic that takes place between an agent's identity displaying independence and an agent's identity displaying dependence as their constitutive features. Traditionally, the former identity has been conceived as corresponding to the man-identity and the latter to the woman-identity. This traditional gender dichotomy has already been conceptually and practically challenged in many different ways and with different normative aims, but what I would like to do here is to consider the pathology of loving recognition as the result of such a dichotomy.

In The Bonds of Love, Benjamin provides an account of gender domination explicitly framed in terms of, as Honneth says, "disorders of love relationships" (Benjamin 1988, 106). Benjamin refers to these disorders as masochism and sadism, concepts that she also uses as metaphors for portraying gender identities. In the traditional, dichotomist, heterosexual organization of the gendered nature of human beings, the woman-identity is overall characterized by masochism and the man-identity by sadism. According to Benjamin, in a (love) relationship between masochist and sadist, the reciprocity of the intersubjective interaction is destroyed by the fact that one of the partners involved is not able to detach himself or herself either from the state of egocentric independence (man-identity) or from symbiotic dependence (woman-identity). Such one-sidedness interrupts the fragile balance between self-affirmation (ego-relatedness) and boundarydissolution (merging with the other, deep loving attachment) and replaces it with a rigid scheme of mutual supplementation or complementarity.

In this and other works, Benjamin analyses the psychological formation of such identities by reconstructing the transition from the preOedipal phase, which basically consists in the dyadic mother-child relation, to the Oedipal phase, marked by the intervention of the father-figure and by the shift from the mutual power-struggle between mother, or caregiver, and child, to paternal authority. Benjamin's considerations are critically addressed especially to those theories (Freudian and Lacanian theories in particular, but to others as well) that take for granted the impossibility of 
achieving recognition within the mother-child dyad.

According to the positions Benjamin criticizes, the father's role is to break dependence and to bring the child to reality and to him or herself, emancipating him or her from what is viewed as an engulfing, absorbing and, therefore, dangerous maternal power (Benjamin 1995, 96). Within these theories (and within those practices that these theories both describe and reproduce), while the only parental work of the mother is that of taking care of the child by satisfying the needs and desires that arise from the child's condition of dependence, the child has to break the dependence bond, to disavow the mother and to struggle for independence with help of the father-figure. The crucial point here is that the mother, as mother, is not (taken to be) someone autonomous and independent enough to be able to teach the child how to struggle for her own power. ${ }^{18}$

The two complementary gender identities are built up through what is called identificatory love, namely, through identification with the parent who corresponds to the same sex of the child. ${ }^{19}$ The man-identity is hence formed through identification with the role performed by the father; such identification entails a series of negative practices against the mother-figure and against what she is supposed to represent (dependence, passivity, symbiotic merging). In order to reach independence, to be constituted as an independent self, dependence, which is represented as experienced within the mothering relation, has to be denied, repressed and defeated.

It is not difficult to understand that this is problematic, especially for the formation of the woman-identity. On the one hand, if the little girl wants to become independent, she has to identify with her father, to love him in the form of an identificatory love, to become like him. The traditional organization of gender identities, however, forbids this kind of love, or better said, this kind of identification through love, and forces the girl to be(come) like the mother. The love for the father, then, can be experienced only in the mode of a complementary love, thus denying her the possibility of developing a fully autonomous, independent identity as a form of womanidentity.

According to Benjamin, the pathology arises because the mother is not recognized as a legitimate partner in relations of recognition, since she is not recognized as someone whose recognition is crucial for the child's achieving independence. The mother is not seen as the "other subject who is sought in the recognition struggle" (Benjamin 1988, 121). The girl's identificatory love for the father cannot be "satisfied within this context of mutual recognition," and it frequently "emerges later as ideal love, the wish for a vicarious substitute for one's own agency" (Benjamin 1988, 122). In this form of pathological love, the woman loves the man in order to realize in him and 
through him that independence she cannot gain and exercise on her own. Identificatory love is then perverted into submission. Love "takes the passive form of accepting the other's will and desires as one's own, from there it is just a step to surrender to the other's will" (Benjamin 1988, 122).

The process of this constitution of the gender dichotomy remains in need of further explication (from a psychoanalytical perspective, as well as others if possible). However, for the purposes of this essay, it is more important to specify precisely what the "splitting of the bond between independence and dependence" means, and how gender identities are to be accordingly conceived.

Firstly, as already mentioned, such a split means that the achievement and exercise of independence is conceived of, and performed as, a violent break with dependence and with all that dependence implies: perceptivity of the neediness of the other, care, support, self-sacrifice, etc. The dependence bond is not perceived and experienced as a condition for independence, autonomy and agency. Rather, dependence and independence are taken as separate, and not as mutually presupposed. Secondly, one can think of the traditional gender dichotomy, namely, of that system of gender identification that envisages only two different and complementary identities, as affected precisely by such a split; the man-identity privileges independence as its peculiar feature, while the woman-identity privileges dependence.

There are various ways in which one can give an account of these two opposite identities by relying on the ideas of dependence and independence. I propose to define woman, within the dichotomist organization of gender identities, as the agent who understands herself as mainly devoted to others, that is to say, as someone whose main activity and responsibility is that of taking care of the other's needs and desires while putting aside her own needs and desires (cf. Kittay 1999, 51-52). According to this interpretation, woman is the agent who takes over the management of other's dependencies, thus attaching herself to a position of dependence on the other. This makes it more difficult for her to strive for independence, to struggle for being recognized as independent, and thus to exercise power or to gain a position of power.

On the contrary, man is defined as the agent who understands himself as mainly focused on achieving and exercising his own independence and being recognized as independent. According to this interpretation, man is the agent who stands in a position of power and exercises his power in order to satisfy his needs and desires; his power is thus a way of making his own dependencies less compelling and binding.

In conclusion, let me recap and better specify the features of the pathological love relation between man and woman. This pathology is mainly 
characterized by the distortion of the dynamic of recognition and the block of the transformative force of love. The two features are interrelated. First, man and woman do not recognize themselves as equal. As a result, they cannot mutually realize themselves by being with the other. In other words, they are not free. Second, power is exercised unilaterally: the domination of one over the other prevents the transformation of those social chains that constitute partners' identities (including gender identities). If the dependence bond cannot be called into question within a dynamic of mutual exercises of power, the pattern of the relation reproduces itself, thus reproducing the gender dichotomy and generating dissatisfaction, unhappiness and suffering.

Federica Gregoratto (federica.gregoratto@unisg.ch) is lecturer in social and political philosophy at the University of St. Gallen, Switzerland. She has published a monograph on Jürgen Habermas' critical theory, edited a volume on recognition, second nature and power, and been a post doc researcher at the University of Frankfurt.

\section{Bibliography}

Benhabib, S. (1996) 'On Hegel, Women and Irony' in P. J. Mills (ed.) Feminist Interpretations of Hegel Pennsylvania: Pennsylvania State UP

Benjamin, J. (1988) The Bonds of Love. Psychoanalysis, Feminism, and the Problem of Domination New York: Pantheon Books

Benjamin, J. (1995) Like Subjects, Love Objects. Essays on Recognition and Sexual Difference New Haven: Yale University Press

Benjamin, J. (2005) 'What Mothers and Babies Need. The Maternal Third and its Presence in Clinical Work' in S. F. Brown (ed.) What Do Mothers Want? Hillsdale: The Analytic Press, pp. 37-54

Finzi, S. V. (1996) Mothering: Towards a New Psychoanalytic Construction New York: Guilford Press

Gauthier, J. A. (1997) Hegel and Feminist Social Criticism Albany: SUNY Press

Honneth, A. (1995) The Struggle for Recognition. The Moral Grammar of Social Conflicts Cambridge: Polity Press 
Honneth, A. (2000) 'Between Justice and Affection: The Family as Field of Moral Disputes' in A. Honneth (2007) Disrespect: The Normative Foundations of Critical Theory Cambridge: Polity Press, pp. 144-162

Honneth, A. (2014) Freedom's Right Cambridge: Cambridge University Press Hutchings, K. (2003) Hegel and Feminist Philosophy Cambridge: Polity Press

Hutchings, K. \& Pulkkinnen, T. (eds.) (2010) Hegel's Philosophy and Feminist Thought: Beyond Antigone? New York: Palgrave

Kittay, E. F. (1999) Love's labor. Essays on Women, Equality, and Dependency New York: Routledge

Kuch, H. (2013) Herr und Knecht. Anerkennung und symbolische Macht im Anschluss an Hegel Frankfurt a.M.: Campus

Okin, S. M. (1982) 'Women and the Making of the Sentimental Family' Philosophy and Public Affairs vol. 11, no. 1

Oliver, K. (2000) ‘Conflicted Love’ Hypatia vol. 15, no. 3

Ring, J. (1991) Modern Political Theory and Contemporary Feminism Albany: SUNY Press

Rössler, B. (2007) 'Work, Recognition, Emancipation' in B. van den Brink \& D. Owen (eds.) Recognition and Power: Axel Honneth and the Tradition of Critical Social Theory Cambridge: Cambridge University Press, pp. 135-163

Rousseau, J.-J. (1979) Emile or On Education New York: Basic Books

Sayers, J. (1987) 'Klein, Psychoanalysis, and Feminism' Feminist Review no. 25 , pp. $23-37$

Stone, A. (2012) Feminism, Psychoanalysis and Maternal Subjectivity New York: Routledge

Young, I. M. (2007) 'Recognition of Love's Labor: Considering Axel Honneth's Feminism' in B. van den Brink \& D. Owen (eds.) Recognition and Power: Axel Honneth and the Tradition of Critical Social Theory Cambridge: Cambridge University Press, pp. 189-212 
Zurn, C. F. (1997) 'The Normative Claims of Three Types of Feminist Struggles for Recognition' Philosophy Today vol. 41, pp. 73-78

\section{Endnotes}

${ }^{1}$ I would like to thank the participants of the workshop "Pathologies of Recognition", Helsinki, May 2014 and of the panel "Ethics of Recognition" at MANCEPT, September 2014, in particular Hans Arentshorst, Alison Beale, Cillian McBride, Gustavo Cunha, Heikki Hikaheimo, Onni Hirvonen, Arto Laitinen, Paddy McQueen and Arvi Särkelä for their comments, criticisms and suggestions on previous drafts of this paper.

2 For feminist critical discussion of Hegel's representation of sexual difference and gender roles see, for instance, Benhabib 1996; Hutchings 2003, Chapters 2, 4-6.

${ }^{3}$ On the relevance of Hegel's thought for feminist theories see, for instance, Ring 1991; Gauthier 1997; Hutchings 2003; Hutchings \& Pulkkinnen 2010.

${ }^{4}$ There are however some scholars who have tried to discuss the category of recognition within gender theory domains; for instance, see Zurn 1997; Kuch 2013.

5 Roughly, one can define identity as the bundle of needs, desires, expectations, habits, beliefs, etc., that regulates and organizes the agent's conduct and life. Gender identities can be here defined as those bundles of needs, desires, expectations, habits, beliefs, etc., that regulate agents' conducts and lives in relation to what is taken as the sexual determination of the agent.

${ }^{6}$ For a critique of Honneth's idea of the social recognition that should be granted to family work, see Rössler 2007.

${ }^{7}$ For instance, see Honneth 2000.

${ }^{8}$ The fact that, despite the actual changes in the gendered division of labor and in the self-understanding of women, the ideology of complementary love does still affect the practices of heterosexual love relationships on a society-wide basis (except, that is, for small elite circles) should be of course empirically validated. One could, for instance, show how the weight of family-work, housework and care-work does still mainly fall on women; 
how women are more likely to put aside their career in favor of family and care duties than their male partners (in fact, the problem of a family-work balance is mainly perceived as a woman's problem); how women are still more supportive, in different ways, of their partner's public life than the other way around. Furthermore, one could also see the enduring violence against women, which takes different forms, as resulting from the frustration of men's expectation that, as Rousseau puts it, the woman "is made specially to please man." (Rousseau 1979, 322). (For instance, see Oliver 2000)

${ }^{9}$ According to this interpretation, friendship, as Honneth reconstructs it (Honneth 2014, 139-140), is also an essential component of love.

${ }^{10}$ Love and love relationships refer to an impressively rich bundle of phenomena that throughout the history of humanity have been described, represented, and analyzed in many different ways and from many different perspectives. The purpose of this essay is not to say what love is, but to show how the paradigm of recognition may be useful for reconstructing (some of) the conditions for a free, successful and happy love relationship.

11 This is of course not the only condition. Before entering the love affair, loving partners have already developed self-awareness, self-consciousness, and the capacity to set goals, elaborate projects and pursue them. The process in which one becomes independent and acts accordingly is however ongoing and never-ending.

${ }^{12}$ For an account of maternal subjectivity that may be helpful for the account of recognition and power I am developing here, see Stone 2012, Chapter 3.

${ }^{13}$ Benjamin has recently investigated the interdependence bond by relying on the idea of "thirdness," which denotes a "quality of the intersubjective exchange that is relevant to the recognition process." (Benjamin 2005). However, in the description of this intersubjective space, Benjamin focuses mainly on the "rhythmical" and harmonious process of mutual recognition between mother and child, thus overlooking the moments of aggression and power. This is due to the fact that her interest in the relevant article is that of clearly distinguishing such a maternal space, or thirdness, from a mode of domination that she describes as "twoness that splits the differences - the polarized opposition of the power struggle." (Benjamin 2005, 38). On this form of domination, see paragraph 3 of this article. 
${ }^{14}$ On the transformation of the mother's identity see, for instance, Finzi 1996, 172.

${ }^{15} \mathrm{I}$ am not arguing that in every moment of every love relation agents challenge and revise their identities. I only argue that the possibility of selftransformation is inherent in the normative understanding of a free love relationship.

${ }^{16}$ This reconstruction assumes that erotic-romantic love is a relation that binds together two agents only. I will not discuss this presupposition here, which is however not to be assumed as entirely unproblematic.

${ }^{17}$ Economic dependence, for example, is often explained as deriving from bonds of love. According to classic explanations, women accept to work for their husbands and partners (housework, care work) for free, only in virtue of their love for them. Hence, such a bond makes women both economically and sentimentally dependent on men; see, for instance, the classic Okin 1982.

${ }^{18}$ For example, Benjamin criticizes Mahler's theory for looking at the motherinfant dyad only from the point of view of the infant that has to go through a process of "individuation" by "separating" herself from the mother. In Mahler's account, the mother is envisioned not as a subject/object of recognition but as the one from whom the child has to distance herself. Notwithstanding, there are other theories, drawing especially on Melanie Klein, that do ascribe a great power to mothers (for instance, see Sayers 1987). According to these theories, however, maternal power is the omnipotent, dangerous power that threatens to completely absorb the other, not the power that establishes separateness, independence and agency.

${ }^{19}$ For a detailed account of identification, and of the role of identification in the constitution of complementary gender identities, see Stone 2012, Chapter 2. 